УДК 796.071.4:338.48-6:502/504:378.091.12:005.336.5

DOI https://doi.org/10.26661/2663-5925-2020-1-05

\title{
ДІАГНОСТИКА СФОРМОВАНОСТІ ФАХОВОЇ КОМПЕТЕНТНОСТІ МАЙБУТНІХ УЧИТЕЛІВ ФІЗИЧНОЇ КУЛЬТУРИ 3 ЕКОЛОГІЧНОГО ТУРИЗМУ
}

\author{
Конох А. П. \\ доктор педагогічних наук, професор, \\ завідувач кафедри теорії та методики фізичної культури і спорту \\ Запорізький національний університет \\ вул. Жуковського, 66, Запоріжжя, Україна \\ orcid.org/0000-0003-4283-9317 \\ konoch105@ukr.net
}

Конох А. А.

кандидат педагогічних наук, викладач кафедри туризму і готельно-ресторанної справи

Запорізький начіональний університет

вул. Жуковського, 66, Запоріжжя, Украӥна

orcid.org/0000-0001-9719-0418

konochaa@ukr.net Ключові слова: майбутній
учитель фізичного виховання,
сфера екологічного туризму,
професійна компетентність.
У статті проаналізовано сучасний стан дослідження проблеми формування фахової компетентності майбутніх викладачів фізичного виховання у сфері екологічного туризму, який підтвердив актуальність і доцільність обраної проблеми, iї недостатню теоретичну розробленість у педагогічній теорії і практиці. Це пов'язано з тим, що спеціалізація «Екологічний та спортивний туризм» відсутня у навчальних планах підготовки майбутніх викладачів фізичного виховання в закладах вищої освіти України.

Доведено, що фахова підготовка майбутніх викладачів фізичного виховання, здатних на високому рівні використовувати екологічний туризм у професійній діяльності, є однією з важливих умов підвищення інтересу дітей і молоді до занять фізичною культурою, туризмом і спортом, забезпечення необхідної рухової активності, розвитку, збереження та зміцнення їхнього здоров'я.

Екологічний туризм визначено як усі форми туризму, що мотивують туристів до спостереження і спілкування з природою, сприяють збереженню довкілля і культурної спадщини, чинячи на них мінімальний вплив. Фахова компетентність викладача фізичного виховання у сфері екологічного туризму розглядається як інтегративна характеристика особистості, що містить сукупність мотивів та інтересів, теоретичні знання, практичні вміння й навички, фахово-важливі якості (фізична підготовленість, креативність і емпатія, комунікативні та організаторські здібності).

Проведення аналізу сутності екологічного туризму, його структури, форм проведення туристичних заходів дало змогу дійти висновку, що фахова підготовка викладача фізичного виховання, компетентного у сфері екологічного туризму, є багатофункціональною. Принциповою специфічною ознакою цієї підготовки $є$ необхідність впровадження інтегрованого підходу до формування іiі змісту, відбору методів і форм, оскільки вона інтегрує фахові знання, вміння та навички, притаманні i викладачу фізичного виховання (дидактичні, академічні, перцептивні, мовні, організаторські, авторитарні, комунікативні), і тренеру-викладачу екологічного туризму (організація навчально-тренувального процесу 3 екологічного туризму). 
Отже, пріоритетною метою формування фахової компетентності майбутніх викладачів фізичного виховання у сфері екологічного туризму єїх підготовка як викладачів фізичного виховання і тренерів-викладачів екологічного туризму. Враховуючи значний попит на фахівців цієї галузі, фахова підготовка майбутніх викладачів фізичного виховання, компетентних у сфері екологічного туризму, має здійснюватися на факультетах фізичного виховання за спеціалізацією «Екологічний та спортивний туризм», адже саме вона враховує особливості цієї підготовки.

\title{
DIAGNOSTICS OF THE FORMATION \\ OF THE PROFESSIONAL COMPETENCE OF THE FUTURE PHYSICAL CULTURE TEACHER FROM ECOLOGICAL TOURISM
}

\author{
Konokh A. P. \\ Doctor of Pedagogical Sciences, Professor, \\ Head of the Department of Theory and Methods of Physical Culture and Sports \\ Zaporizhzhia National University \\ Zhukovskoho str., 66, Zaporizhzhia, Ukraine \\ orcid.org/0000-0003-4283-9317 \\ konoch105@ukr.net \\ Konokh A. A. \\ Candidate of Sciences in Pedagogy, \\ Lecturer at the Department of Tourism and Hotel and Restaurant Business \\ Zaporizhzhia National University \\ Zhukovskoho str., 66, Zaporizhzhia, Ukraine \\ orcid.org/0000-0001-9719-0418 \\ konochaa@ukr.net
}

Key words: future teacher of physical education, sphere of ecological tourism, professional competence.
The analysis of the current state of formation of professional competence of future teachers of physical education in ecological tourism has confirmed the relevance and feasibility of the research problem, its unsufficient theoretical development in pedagogical theory and practice. The analysis of the current state of formation of professional competence of future teachers of physical education in ecological tourism has confirmed the relevance and feasibility of the research problem, its unsufficient theoretical development in pedagogical theory and practice.

This related to the fact that the specialization "Ecological and sports tourism" has not been included into the curricula of training of future teachers of physical education in higher education institutions in Ukraine. It has been proved that professional training of future teachers of physical education, who are able to use at a high level ecotourism in professional activity, is one of the important condition for increasing interest of children and youth in physical education, tourism and sports, providing the necessary physical activity, development, preservation and strengthening their health.

Conducting the analysis of the nature of eco-tourism, its structure, forms of tourist activities conducting, has made it possible to conclude that the professional training of a teacher of physical education, who is competent in the field of eco-tourism, is multifunctional. The main specific feature of this training is the need to introduce an integrated approach to the formation of its content, selection of methods and forms, as it integrates the professional knowledge, skills which are characteristic both to the teacher of physical education (didactic, academic, perceptive, organizational, perceptive, 
organizational etc.) and to the trainer-teacher of eco-tourism (organization of educational-training process on eco-tourism).

It is determined that the priority purpose of forming the professional competence of future teachers of physical education in eco-tourism is their training as a teachers of physical education and coache-teachers of ecotourism. The professional competence of the teacher of physical education in eco-tourism is considered as an integrative characteristic of the individual, which contains a set of motives and interests, theoretical knowledge, practical skills, professionally important qualities (physical fitness, creativity and empathy, communicative and organizational abilities).

It is proved that, taking into consideration, the considerable demand for specialists in this field, the professional training of future teachers of physical education, who are competent in ecological tourism, should be carried out at the faculties of physical education on the specialization "Ecological and sports tourism", because this specialization takes into consideration the peculiarities of this training. The professional competence of a physical education teacher in the field of eco-tourism is considered as an integrative characteristic of personality, containing a set of motives and interests, theoretical knowledge, practical skills, professionally important qualities (physical fitness, creativity and empathy, communication and organizational skills).

Постановка проблеми. В сучасних умовах урбанізації, комп'ютеризації, загострення демографічних проблем, погіршення екологічного стану в Україні важливого значення набуває повноцінний фізичний розвиток підростаючого покоління, реалізація здоров'язберігаючої функції організму людини. Одним із важливих напрямів підготовки висококваліфікованих фахівців 3 вищою освітою $є$ підготовка фахівців у галузі фізичної культури, зокрема $з$ екологічного туризму.

Розв'язання цієї проблеми потребує нагального впровадження у систему освіти ефективних заходів щодо зміцнення фізичного й психічного здоров'я дітей і молоді, формування здорового способу життя, цінностей активного, розвивального, просоціального дозвілля, що зазначено у відповідних нормативних документах: Законах України «Про вищу освіту» (2014), «Про фізичну культуру і спорт» (1993), «Про туризм» (1994), в Указі Президента України «Про національну стратегію з оздоровчої рухової активності в Україні на період до 2025 року», «Концепції розвитку освіти в Україні на період 2015-2025 рр.», «Концепції Загальнодержавної програми «Здоров’я 2020: український вимір» на 2012-2020 рр.».

Аналіз психолого-педагогічної літератури 3 проблеми фахової підготовки майбутніх вчителів фізичної культури в умовах закладів вищої освіти свідчить про значну увагу науковців до іiї дослідження. Так, дослідженнями професійної підготовки майбутніх фахівців екологічного туризму займалися як зарубіжні (О. Косолапов [1] та інші), так і вітчизняні вчені (О. Дмитрук, С. Дмитрук [2], К. Мулик, М. Носко [3] та інші).
Незважаючи на значний інтерес науковців до питань професійної підготовки майбутніх фахівців фізичної культури і спорту, проблема формування фахової компетентності вчителів фізичної культури у сфері екологічного туризму як у теоретичному, так і в практичному аспектах є малодослідженою, що насамперед зумовлено новітнім характером явища екологічної діяльності, а також невизначеністю науково-методичних засад підготовки педагогів до її здійснення.

Метою статті $\epsilon$ визначення рівня сформованості знань, умінь та навичок з екологічного туризму у студентів факультету фізичного виховання спеціальності 017 «Фізична культура і спорт» освітньої програми «Фізичне виховання».

Виклад основного матеріалу дослідження. 3 метою підтвердження актуальності порушеної проблеми та 3'ясування існуючого стану сформованості фахової компетентності майбутніх вчителів фізичної культури з екологічного туризму проведено дослідження, завданнями якого було визначити особливості розуміння студентами необхідності використання екологічного туризму в фаховій підготовці майбутніх учителів фізичної культури; визначити відсоток студентів, зацікавлених у вивченні екологічного туризму; визначити ставлення викладачів закладів вищої освіти щодо доцільності формування фахової компетентності майбутніх вчителів фізичної культури до організації екологічного туризму; визначити готовність учителів фізичної культури до використання екологічного туризму у своїй професійній діяльності; визначити причини, які негативно впливають на впровадження екологічного туризму у навчально-виховний процес закладів освіти. 
Дослідження проведено на базі факультетів фізичного виховання шести закладів вищої освіти, в якому брали участь студенти 4 курсу спеціальності 017 «Фізична культура і спорт» освітньої програми «Фізичне виховання», викладачі факультету фізичного виховання, які викладають дисципліни, пов'язані з туристичною діяльністю, та вчителі фізичної культури закладів середньої освіти м. Запоріжжя.

Аналіз результатів анкетування показав, що із 490 опитаних студентів на запитання: «Чи вважаєте Ви за необхідне здійснювати у закладах вищої освіти України фахову підготовку майбутніх викладачів фізичного виховання у сфері екологічного туризму?» були отримані такі результати: за необхідне висловилися 79,39\% (389 осіб) студентів; не вважають $-9,18 \%$ (45 осіб); не визначилися $11,43 \%$ (56 осіб) студентів. Більшість студентів, a саме $79,39 \%$ опитаних, вважають за доцільне здійснення їх підготовки до використання екологічного туризму у професійній діяльності, що підкреслює вагомість та актуальність порушеної в роботі проблеми дослідження.

Відповіді студентів на запитання анкети: «Чи володієте Ви знаннями щодо законодавства України з екологічного туризму?» показали, що володіють знаннями щодо законодавства України з екологічного туризму $1,84 \%$ (58) студентів, частково володіють $51,22 \%$ (251) респондентів, не володіють - 30,82\% (151) респондентів, вагалися відповісти $-6,12 \%$ (30) студентів. Отже, переважна більшість опитаних студентів лише частково володіє знаннями щодо законодавства України щодо екологічного туризму.

Аналіз відповідей студентів на запитання анкети: «Наскільки Ви особисто підготовлені до застосування екологічного туризму в майбутній професійній діяльності?» продемонстрував, що підготовленими до застосування екологічного туризму у майбутній професійній діяльності себе вважають $3,88 \%$ (19) студентів, частково - 31,02\% (152) респондентів, не володіють - 43,88\% (215) респондентів, вагалися відповісти - 21,22\% (104) студентів. Тільки $3,88 \%$ опитаних студентів (п'ята частина) особисто підготовлені до застосування екологічного туризму у майбутній професійній діяльності.

Результати аналізу відповідей студентів на запитання анкети: «Чи вважаєте Ви за потрібне застосування окремих модулів 3 екологічного туризму у змісті окремих дисциплін фахової підготовки бакалаврів?» продемонстрували, що вважають за потрібне $35,71 \%$ (175) студентів, не вважають 8,78\% (43) респондентів, переважна більшість $(51,63 \%)$ (253) студентів лише частково підтримують, вагалися відповісти 3,88\% (19) студентів. Отримані результати підтверджують низь- кий рівень знань, явну недооцінку студентами значення екологічного туризму, його великого потенціалу у зміцненні здоров'я дітей і молоді.

Для цього дослідження важливим було 3'ясування результатів анкетування студентів щодо володіння ними знаннями про сутність, мету, завдання й зміст роботи вчителів фізичної культури у сфері екологічного туризму. За результатами анкетування було з'ясовано, що володіють знаннями про сутність, мету, завдання й зміст фахової роботи вчителя фізичної культури з використанням засобів екологічного туризму $11,22 \%$ (55) респондентів; частково володіють 50,61\% (248); не володіють знаннями 24,69\% (121); важко було відповісти $13,47 \%$ (66) опитаних студентів.

Отже, тільки незначна кількість опитаних студентів, а саме 11,22\%, вважають, що володіють знаннями про зміст роботи вчителів фізичної культури з екологічного туризму. Це свідчить про необхідність проведення дослідження 3 проблеми фахової компетентності майбутніх вчителів фізичної культури у сфері екологічного туризму.

За результатами проведеного анкетування на запитання: «Як Ви вважаєте, чи досить Ви володієте знаннями з екологічного туризму?» відповіді студентів були такими: володіють цими знаннями $4,49 \%$ (22) студентів, частково володіють $25,71 \%$ (126), не володіють 66,12\% (324), вагалися відповісти 3,68\% (18) студентів. Загалом переважна більшість студентів $(66,12 \%)$ не володіють знаннями з екологічного туризму.

Важливо зауважити, що результати відповідей студентів на запитання: «Чи володієте Ви знаннями щодо організації та проведення екологічних туристських заходів?» також є незадовільними, адже володіють цими знаннями лише 9,18\% (45) студентів, частково володіють цими знаннями $18,99 \%$ (93) респондентів, не володіють $67,14 \%$ (329), вагалися відповісти 4,69\% (23) студентів, які зауважили про негативний стан сучасної професійної підготовки майбутніх вчителів фізичної культури у закладах вищої освіти України.

На запитання: «Чи вмієте Ви працювати 3 туристичними електронними довідниками-каталогами й методичною туристською літературою?» відповіді були такими: володіють цими знаннями $11,02 \%$ (54) студентів, частково володіють $20 \%$ (98), не володіють $62,45 \%$ (306), вагалися відповісти $8,47 \%$ (32) студентів.

Результати відповідей студентів на запитання: «Чи вважаєте Ви, що формування фахової компетентності у сфері екологічного туризму сприятиме підвищенню Вашої кваліфікації?» показали, що сприятиме для 43,47\% (213), студентів, частково $23,47 \%$ (115), не вважають 25,51\% (125) респондентів, вагалися відповісти 7,55\% (37) студентів. Переважна більшість студентів $(43,47 \%)$ 
вважають, що формування фахової компетентності у сфері екологічного туризму сприятиме підвищенню їх кваліфікації.

На запитання про забезпечення студентів навчально-методичним забезпеченням 3 екологічного туризму лише $15,10 \%$ (74) студентів відповіли, що вони задоволені наявним навчально-методичним забезпеченням, частково задоволені 45,31\% (222), не задоволені 27,14\% (133), важко було відповісти 12,45\% (61) респондентів. Отриманні дані засвідчили гостру потребу у забезпеченні студентів навчально-методичним забезпеченням, необхідним для їхньої майбутньої професійної діяльності.

Не дуже позитивними виявилися результати відповідей студентів на запитання: «Чи володієте Ви термінологією екологічного туризму?». Цими знаннями володіють лише $11,63 \%$ (57) студентів, не володіють $32,86 \%$ (161) респондентів, частково володіє переважна більшість студентів 46,94\% (230), вагалися відповісти 8,57\% (42) студентів. Не володіння фаховою термінологією, необхідною для використання в сфері екологічного туризму, вказує на те, що професорсько-викладацькому складу закладів вищої освіти необхідно приділяти цьому питанню більше уваги.

Отже, фахова підготовка майбутніх вчителів фізичної культури розглядається як цілісна система, яка будується на основі органічного об'єднання загального та індивідуального розвитку особистості. Результати дослідження дозволили визначити недостатню зацікавленість студентів факультету фізичного виховання екологічним туризмом, причиною якої є низький рівень знань щодо нього; необхідність застосування екологічного туризму у фаховій підготовці фахівців сфери фізичної культури; необхідність активного залучення студентів до вивчення екологічного туризму.

3 метою 3'ясування стану підготовки майбутніх викладачів фізичного виховання до використання екологічного туризму у професійній діяльності і готовності викладачів до формування фахової компетентності майбутніх вчителів фізичної культури у сфері екологічного туризму було проведено анкетування викладачів закладів вищої освіти України.

Серед 162 опитаних респондентів вважають за доцільне формування фахової компетентності майбутніх вчителів фізичної культури у сфері екологічного туризму 90,74\% (147 особи) викладачів, вважають недоцільним 6,17\% (10 осіб), важко було відповісти 3,09\% (5 осіб) респондентів. Це підкреслює важливість формування фахової компетентності майбутніх вчителів фізичної культури у сфері екологічного туризму.

Аналізуючи відповіді опитаних викладачів закладів вищої освіти про доцільність вве- дення спеціалізації «Екологічний та спортивний туризм» у навчальний процес фахової підготовки майбутніх вчителів фізичної культури, можна стверджувати, що вважають за доцільне введення спеціалізації 91,98\% (149 осіб) викладачів, недоцільним здійснювати таку підготовку - 5,55\% (9 осіб), важко було відповісти 2,47\% (4 особам) респондентів. Отримані дані анкетування підкреслюють важливість фахової підготовки майбутніх вчителів фізичної культури до використання екологічного туризму у їх професійній діяльності.

Для цього дослідження було важливим 3'ясувати питання про доцільність і проведення ефективних форм практичної підготовки майбутніх вчителів фізичної культури 3 екологічного туризму. На питання: «Чи вважаєте Ви за доцільне проводити польові туристські табори 3 майбутніми вчителями фізичної культури?» 93,83\% (152 особи) опитаних викладачів відповіли ствердно, частково вважають 4,94\% (8 осіб), не вважають 1,23\% (2 особи) викладачів.

Отримані результати анкетування дали підставу констатувати, що тільки 19,75\% (32 особи) опитаних викладачів задоволені існуючою науково-методичною літературою, необхідною для здійснення фахової підготовки майбутніх вчителів фізичної культури до використання екологічного туризму у своїй професійній діяльності, незадоволені 46,30\% (75 осіб), частково задоволені $32,10 \%$ (52 особи), важко було відповісти $1,85 \%$ (3 особам) викладачів.

Аналіз цих даних потребує термінового розгляду з боку науковців і спрямування їхніх зусиль на написання відповідної науково-методичної літератури. Відповіді опитаних викладачів про те, чи проводять вони фестивалі і олімпіади, фізкультурно-спортивні свята серед майбутніх вчителів фізичної культури з використанням екологічного туризму свідчать, що проводять фестивалі і олімпіади 20,99\% (34 особи) опитаних викладачів, інколи проводять $32,71 \%$ (53 особи), не проводять $43,83 \%$ (71), важко було відповісти 2,47\% (4 особам) респондентів.

За результатами опитування викладачів закладів вищої освіти можна зробити висновок, що регулярно проводять студентські науково-практичні конференції на теми, пов'язані з використанням екологічного туризму та їх оздоровчо-виховним впливом на стан здоров'я дітей і молоді, тільки 10,49\% (17 осіб) викладачів; інколи проводять $30,25 \%$ (49 осіб); не проводять $57,41 \%$ (93 особи); важко було відповісти 1,85\% (3 особам) респондентів.

Професійна діяльність майбутнього вчителя фізичної культури пов'язана з необхідністю особистісного показу фізичних вправ, здійсненням страховки та наданням допомоги під час організації та 
проведення заходів туристичної спрямованості, різноманітною руховою активністю, яка потребує від фахівця високого рівня фізичної підготовленості.

Аналіз відповідей 162 опитаних викладачів показав, що 87,65\% (142 особи) респондентів вважають, що майбутній вчитель фізичної культури, який організовує і проводить туристичні походи, зльоти, екскурсії, повинен бути фізично підготовленим, частково вважають 8,03\% (13), не вважають 2,47\% (4); важко було відповісти 1,85\% (3 особам) респондентів.

Одним із важливих питань цього дослідження було з'ясувати про доцільність проведення педагогічної практики майбутніх вчителів фізичної культури у туристичних клубах, центрах. Результати дослідження свідчать, що 69,14\% (112 осіб) опитаних викладачів вважають за доцільне проведення педагогічної практики майбутніх вчителів фізичної культури у туристичних клубах, центрах, частково вважають 24,07\% (39 осіб), не вважають 4,32\% (7 осіб), важко було відповісти 2,47\% (4 особам) викладачів.

Отримані результати опитування викладачів закладів вищої освіти свідчать про недооцінку ними важливості екологічного туризму під час фахової підготовки майбутніх вчителів фізичної культури. Необхідно проводити дослідження 3 проблеми формування фахової компетентності майбутніх вчителів фізичної культури у сфері екологічного туризму.

Для більш об'єктивного з'ясування окремих аспектів фахової компетентності майбутніх вчителів фізичної культури у сфері екологічного туризму було проведено анкетування 246 вчителів фізичної культури закладів середньої освіти Запорізької області під час проходження ними курсів підвищення кваліфікації. Відповіді опитаних вчителів фізичної культури на питання, чи відповідає сучасним вимогам рівень готовності вчителів фізичної культури до використання екологічного туризму у своій професійній діяльності, розділилися.

Так, вважають, що він відповідає сучасним вимогам 7,32\% (18 осіб) респондентів, що частково відповідає 25,61\% (63 особи), не відповідає $60,57 \%$ (149 осіб), було важко відповісти 6,50\% (16 особам) респондентів. Отже, лише 7,32\% опитаних вчителів фізичної культури вважають, що рівень їхньої готовності до використання екологічного туризму у своїй професійній діяльності відповідає сучасним вимогам.

На підставі опитування вчителів фізичної культури була визначена домінуюча за оцінкою позиція, яка відображає їх зацікавленість у використанні екологічного туризму та позитивне ставлення до проведення занять із використанням екологічного туризму.

Серед опитаних вчителів фізичної культури 70,32\% (173 особи) дали позитивну відповідь,
23,98\% (59 осіб) вчителів фізичної культури вважають можливим сполучення традиційних засобів фізичного виховання та використання екологічного туризму поряд з іншими, не можуть визначитися 2,85\% (7 осіб).

Слід зазначити, що $є$ група вчителів фізичної культури, які налаштовані негативно, не хочуть виконувати роботу в цьому напрямі, тому що не вірять у потенційні можливості використання екологічного туризму і не хочуть самовдосконалюватися, або ті, які працюють за сумісництвом, $\mathrm{i}$ повноцінний процес роботи їх не цікавить. Таких учителів фізичної культури зараховано до окремої групи, яка становить 2,85\% (7 осіб).

Отримані результати анкетування дають змогу зробити висновок щодо явної недооцінки вчителями фізичної культури значення екологічного туризму, його позитивного впливу на здоров'я дітей і молоді, їх невіру у свої можливості. Для цього дослідження було важливим з'ясувати, які причини негативно впливають на впровадження екологічного туризму у навчально-виховний процес закладів освіти, визначити напрями формування позитивного ставлення до екологічного туризму.

За результатами відповідей учителів фізичної культури причини, що негативно впливають на впровадження екологічного туризму у практику закладів освіти, можна розташувати в такій послідовності: недостатність знань, умінь і навичок в учителів фізичного виховання щодо використання екологічного туризму у $34,96 \%$ (86 осіб); недостатня мотивація щодо використання екологічного туризму у професійній діяльності - 23,58\% (58 осіб); недостатність спортивного обладнання та інвентарю для впровадження екологічного туризму - 18,70\% (46 осіб); недостатня розробленість і якість навчально-методичного забезпечення впровадження екологічного туризму - $11,79 \%$ (29 осіб); незадовільні матеріально-технічні умови для впровадження екологічного туризму $8,54 \%$ (21 особа); інші причини - 2,43\% (6 осіб).

Щодо напрямів формування позитивного ставлення до екологічного туризму у дітей і молоді, то 37,40\% (92 особи) вчителів фізичної культури прагнуть розширення мережі туристичних секцій, клубів, груп за інтересами; 32,93\% (81 особа) висловилися за активне залучення громадськості до пропаганди здорового способу життя серед школярів засобами екологічного туризму; 17,48\% (43 особи) - за використання інноваційних програм і технологій у роботі зі школярами; $12,19 \%$ (30 осіб) - щодо підтримки молодіжних ініціатив з питань передачі достовірної соціально-значущої інформації серед ровесників.

Під час експерименту було з'ясовано, що ставляться 3 великою зацікавленістю та прагнуть 
використовувати екологічний туризм у професійній діяльності 79,39\% майбутніх вчителів фізичної культури, 90,74\% викладачів закладів вищої освіти, 70,32\% вчителів фізичної культури. Лише 7,32\% опитаних вчителів фізичної культури вважають, що їх рівень готовності до використання екологічного туризму у своїй професійній діяльності відповідає сучасним вимогам. Головною причиною цього вчителі фізичної культури називають недостатній рівень знань, практичних умінь та навичок. Загалом же вчителі фізичної культури здебільшого не розуміють потенційних можливостей використання екологічного туризму і їх переваги над традиційними видами фізичної культури і спорту, що застосовуються у практиці.

Висновки. Здійснений комплексний науковий аналіз засвідчив, що формування фахової компе- тентності майбутнього вчителя фізичної культури у сфері екологічного туризму доцільно здійснювати саме в системі вищої освіти, адже вона $\epsilon$ складником їх професіоналізму та має свою специфіку. Визначені особливості полягають у тому, що він має володіти фаховими вміннями та навичками, притаманними як викладачу, вчителю фізичної культури, так і спеціалісту з екологічного туризму. Одним зі шляхів вирішення цієї проблеми має бути впровадження до спеціальності 017 «Фізична культура і спорт» освітньої програми «Фізичне виховання» спеціалізації «Екологічний та спортивний туризм».

Перспективами подальших досліджень вважаємо здійснення комплексної оцінки рівня сформованості знань, умінь та навичок з екологічного туризму у магістрів факультету фізичного виховання.

\section{ЛІТЕРАТУРА}

1. Косолапов А.Б. Теория и практика экологического туризма : учеб. пособ. Москва : КНОРУС, 2005. $240 \mathrm{c}$.

2. Дмитрук О.Ю., Дмитрук С.В. ЄКОтуризм : навч. посіб. Київ : Альтерпрес, 2009. 358 с.

3. Мулик К.В., Носко М.О. Диференційований підхід до підготовки фахівців зі спортивно-оздоровчого туризму для роботи 3 дітьми, підлітками та студентською молоддю. Вісник Чернігівського національного педагогічного університету. Серія: Педагогічні науки. Фізичне виховання та спорт. 2015. Вип. 129(2). С. 217-222.

\section{REFERENCES}

1. Kosolapov A.B. (2005). Teoryia y praktyka ekolohycheskoho turyzma : ucheb. posob. [Theory and practice of ecological tourism]. Moscow, 240 p. [in Russian].

2. Dmitruk O.Yu., Dmitruk S.V. (2009). EKOturyzm : navch. posib. [ECOTourism : textbook]. Kyiv : Alterpress, 358 p. [in Ukrainian].

3. Mulyk K.V., Nosko M.O. (2015). Dyferentsiiovanyi pidkhid do pidhotovky fakhivtsiv zi sportyvno-ozdorovchoho turyzmu dlia roboty z ditmy, pidlitkamy ta studentskoiu moloddiu. [Differentiated approach to the training of specialists in sports and health tourism to work with children, adolescents and students]. Bulletin of Chernihiv National Pedagogical University. Series: Pedagogical sciences. Physical education and sports, № 129(2), P. 217-222 [in Ukrainian]. 